einstein

Official Publication of the Instituto Israelita

de Ensino e Pesquisa Albert Einstein

ISSN: 1679-4508 | e-ISSN: 2317-6385
LETTER TO THE EDITOR

\section{Biobanks: a basis for quality research}

\author{
Biobancos: uma base para pesquisas \\ de qualidade
}

\author{
Igor Carreiro Ramalho', Carlos Magno da Costa Maranduba' \\ 1 Universidade Federal de Juiz de Fora, Juiz de Fora, MG, Brazil.
}

DOI: 10.31744/einstein_journal/2020CE5266

Dear Editor,

Considering that today there is a growing concern with the quality of cells, tissues, and organs destined for the treatment of human diseases, within this context, many studies have been conducted by public institutions. Several organizations store biological samples and data, given the difficulty to obtain and characterize many of these materials, as they can possibly be used in new projects. Based on the current legislation, storage, as mentioned, characterizes a biobank..$^{(1)}$ These structures require investment for maintenance of the samples stored. Today we have private units that have their own resources for deposits of private samples, with a limited use of the samples, in addition to public biobanks, in which the certified samples can be used for different purposes, guaranteeing the benefit of their serviceability; for those destined to research, carrying out projects with samples and/or quality biological data. ${ }^{(2-4)}$

Today, Brazil has 53 regulated biobanks and a few others in course. ${ }^{(1)}$ Observing the world scenario as to human biological samples, the United States has 169 biobanks, while Europe has 90, and Asia, 23. There are yet 26 additional biobanks for storage of samples of animals and plants distributed over 12 countries. ${ }^{(5)}$ In face of this world scenario, it is crucial that competent authorities understand the need for and the importance of investments in this sector, in order to improve the excellence of research done in Brazil. The lack of investments in these structures directly impacts the quality of the outcome of products and services that society looks forward to. ${ }^{(6)}$ Therefore, it is vital that Brazil have its position set in this scenario, with biobanks of high structural and operational standards, placing our country on equal terms with developed countries.

\section{AUTHORS' INFORMATION}

Ramalho IC: http://orcid.org/0000-0003-1227-2321

Maranduba CM: http://orcid.org/0000-0001-7327-1934

\section{REFERENCES}

1. Brasil. Ministério da Saúde. Conselho Nacional de Saúde (CNS). Biobancos [Internet]. Brasília (DF): CNS; 2019 [citado 2019 Jun 18]. Disponível em: http://conselho.saude.gov.br/0-que-e-rss/92-comissoes/conep/ normativas-conep/647-biobancos-conep 
2. Barini R, Ferraz UC, Acácio GL, Machado IN. Does the time between collecting and processing umbilical cord blood samples affect the quality of the sample? einstein (São Paulo). 2011;9(2):207-11.

3. Todaro J, Manhani AR, Kutner JM, Ribeiro AA, Rodrigues M, Kerbauy FR, et al. Autologous stem-cell transplantation for multiple myeloma: a Brazilian institution experience in 15 years of follow-up. einstein (São Paulo). 2011;9(2):119-23.
4. Glina S, Nova T, Brand VB, Molina E, Galuppo AG, Correa NR, et al. Evaluation of semen parameters in semen donors in a ten-year period in the city of São Paulo. einstein (São Paulo). 2010;8(4):423-9.

5. SpecimenCentral. Global Biobank Directory, Tissue Banks and Biorepositories [Internet]. Minnesota: Specimen Central; 2019 [cited 2019 June 3]. Available from: https://specimencentral.com/biobank-directory/\#European\%20Biobanks

6. Pasternak J. Corruption. einstein (São Paulo). 2017;15(3):11-2. 